\title{
EVALUASI PENGGUNAAN OBAT ANTITUBERKULOSIS (OAT) PADA PASIEN TB PARU DI RUMAH SAKIT GRANDMED
}

\section{LUBUK PAKAM TAHUN 2020}

\section{Amanda Safithri Sinulingga ${ }^{1}$, Novidawati Boru Situmorang ${ }^{2}$, Mas Gabena Siregar ${ }^{3}$}

\author{
INSTITUT KESEHATAN MEDISTRA LUBUK PAKAM \\ Jl. Sudirman No.38, Petapahan, Kec. Lubuk Pakam \\ Kabupaten Deli Serdang, Sumatera Utara 20512 \\ e-mail : amandashafitrisinulingga@gmail.com \\ DOI $10.35451 / \mathrm{jfm} . v 3 \mathrm{i} 2.576$
}

\begin{abstract}
Tuberculosis is a disease caused by the bacteria Mycobacterium tuberculosis, the first line of anti-tuberculosis drugs, namely Isoniazid $(H)$ and Rifampicin (R). The increase in the number of TB Lung patients from 2019 to 2020 at Grandmed Lubuk Pakam Hospital encouraged researchers to conduct this research. The purpose of this study was to describe the use of antituberculosis drugs and the rationality of using anti-tuberculosis drugs in pulmonary TB patients at Grandmed Lubuk Pakam Hospital in 2019. This study was a descriptive (non-experimental) study. with retrospective data collection taken from patient medical records. Pulmonary tuberculosis at Grandmed Lubuk Pakam Hospital. The data was collected by using purposive sampling technique in accordance with the inclusion criteria and exclusion criteria using the Data Collection Sheet. The number of samples used in the study were 76 medical records of patients diagnosed with pulmonary tuberculosis. Data analysis was performed using Univariate with the help of SPSS. The results of the data distribution of the length of treatment, most of the patients underwent treatment for <6 months, as many as 31 people (19.9\%). Followed by patients for exactly 6 months as many as 30 people (0.39\%). While patients from 6 months were 16 (21.1\%). And the number of chronic diseases suffered by Diabetes Mellitus patients was 24 patients (14.5\%). All three have a significant relationship with patient treatment outcomes. Meanwhile, in the age range 18 24 years, 44 people (57.9\%) were affected by pulmonary tuberculosis. and the results of the evaluation of the rationality of pulmonary TB treatment, there are correct indications (97.4\%), (74 patients), 100\% correct patient (76 patients), right drug (97.4\%) (74 patients)), and correct dosage. correct $100 \%$ (76).
\end{abstract}

Keywords: Oat Drugs, Rs Granmed Lubuk Pakam.

\section{PENDAHULUAN}

Tuberkulosis (TB) merupakan suatu penyebab kematian terbesar setelah penyakit kardiovaskular dan saluran pernapasan nomor satu dari golongan penyakit infeksi yang masih menjadi permasalahan di Indonesia maupun di dunia. Bakteri Mycobacterium tuberculosis ini penyakit yang berbahaya pada manusia, dimana merupakan reservoir untuk bakteri ini. Mycobacterium tuberculosis 
menginfeksi secara silent (sunyi), laten (tersembunyi) dan juga aktif (Kenneth, 2011).

Kuman ini paling sering menyerang organ paru dengan sumber penularan adalah pasien TB BTA positif. Sampai saat ini TB masih menjadi masalah kesehatan yang utama diberbagai Negara di dunia. World Health Organitation (WHO) memperkirakan antara tahun 2002-2020 sekitar 1 miliar manusia akan terinfeksi TBC, jika dihitung pertambahan jumlah pasien TBC, bertambah sekitar 2,8-5,6 juta setiap tahun dari 1,1 hingga 2,2 juta jiwa meninggal setiap tahun (Anggreini, 2011).

Secara global, tahun 2018 terdapat 11,1 juta kasus insiden TB paru dimana setara dengan 130 kasus per 100.000 penduduk. Indonesia merupakan negara dengan insiden kasus tertinggi kedua setelah India. Berdasarkan usia sebanyak $57 \%$ kasus menyerang pria yang berusia lebih dari 15 tahun, wanita $32 \%$. Beberapa Negara yang menjadi peringkat pertama untuk kejadian TB paru yaitu India dengan presentase $27 \%$, Cina 9\%, Indonesia 8\%, Nigeria 4\%, Bangladesh 4\% dan Afrika Selatan sebanyak $3 \% \quad$ (World Health Organization Global Tuberculosis Report, 2019). Dengan peningkatan efek teraupetikklinis, meminimalkan toksisitas obat dan meminimalkan terjadinya resisten (Kementrian Kesehatan RI 2014). Sedangkan penggunaan obat yang tidak tepat dapat menimbulkan bermacam masalah seperti ketidak sembuhan penyakit, peningkatan resiko efek samping obat dan serta peningkatan biaya pengobatan dan resistensi (Nurmala, et al., 2015).

Atas semua dasar tersebut diatas, sehingga peneliti tertarik untuk melakukan penelitian terkait evaluasi penggunaan OAT pada pasien penyakit Tuberkulosis Paru di Rumah Sakit Grandmed Lubuk Pakam yang mencakup, kesesuaian penggunaan terhadap standar pedoman. karena adanya peningkatan jumlah pasien dari tahun 2019-2020 di Rumah sakit Grandmed Lubuk Pakam tahun 2020. Dilakukannya evaluasi penggunaan obat Antituberkulosis ini untuk mengetahui apakah pengobatan yang selama ini diberikan kepada pasien sudah sesuai dengan standar dari Pedoman Nasional Penanggulangan Tuberkulosis DepKes RI tahun 2018.

\section{Metode}

Penelitian ini menggunakan metode deskriptif, yaitu penelitian yang bertujuan untuk mendapatkan gambaran atau deskripsi tentang suatu keadaan secara objektif, pengambilan data dilakukan secara retrospektif yaitu suatu penelitian yang mengkaji informasi atau mengambil data yang telah lalu dengan menggunakan data sekunder yaitu data yang diperoleh secara tidak langsung dari rekam medic yang sudah berlalu (Benardi, 2015).

Populasi adalah totalitas semua nilai yang mungkin baik hasil menghitung maupun hasil mengukur baik kualitatif maupun kuantitatif dari karakteristik mengenai sekumpulan objek yang lengkap dan jelas (Siswanto,2014). Populasi dalam penelitian ini adalah seluruh pasien TB paru di Rumah Sakit Grandmed Lubuk Pakam pada periode januari 2019 s/d Desember 2019 sebanyak 236 orang.

Sampel adalah bagian jumlah dan karakteristik yang dimiliki oleh populasi tersebut (Sugiyono, 2014). Sampel dalam penelitian ini adalah pasien TB paru di Rumah Sakit Grandmed Lubuk Pakam pada tahun 2019. Dimana sampel yang diambil 
berdasarkan rumus Lemeshow.

\section{HASIL DAN PEMBAHASAN}

Dari Data Rekam Medik Pasien TB Paru Di Rumah Sakit Grandmed Lubuk Pakam pada bulan januari 2019 s/d desember 2019 terdapat 76 pasien yang terdiagnosa Tb Paru.

\section{Distribusi Karakteristik Responden Berdasarkan Jenis Kelamin dan Usia}

\section{Jenis Kelamin}

Berdasarkan penelitian yang dilakukan terhadap Evaluasi Penggunaan Antituberkulosis Pada Pasien TB Paru di Rumah Sakit Grandmed Lubuk Pakam Tahun 2020 diperoleh gambaran penggunaan obat Antituberkulosis untuk pasien TB Paru dapat dilihat pada Tabel 1.

Tabel 1. Distribusi Jenis Kelamin Pasien TB Paru Di Rumah Sakit Grandmed Lubuk Pakam Periode Januari 2019 S/D Desember 2019

\begin{tabular}{lccl}
\hline $\begin{array}{l}\mathbf{N} \\
\mathbf{0}\end{array}$ & $\begin{array}{c}\text { Jenis } \\
\text { Kelamin }\end{array}$ & $\mathbf{F}$ & $\begin{array}{c}(\mathbf{\%}) \\
(\mathbf{n = 7 6 \% )}\end{array}$ \\
\hline 1 & Laki-Laki & 44 & $57.9 \%$ \\
\hline 2 & Perempuan & 32 & $42.1 \%$ \\
\hline \multicolumn{2}{l}{ Total } & 76 & $100.0 \%$ \\
\hline
\end{tabular}

Berdasarkan dari Tabel 1. Diketahui bahwa jumlah pasien TB paru di Rumah Sakit Grandmed Lubuk Pakam Tahun 2020 sebanyak 76 pasien. Untuk lakilaki penderita TB Paru berjumlah 44 Pasien (57.9\%). Kemudian untuk perempuan penderita TB paru berjumlah 32 pasien (42.1 \%). Prevalensi ini menyimpulkan bahwa jumlah penderita berjenis kelamin lakilaki lebih banyak daripada perempuan. $\mathrm{Hal}$ ini terlihat dari persentase penderita laki-laki (57.9\%) sedangkan perempuan (42.1\%).

\section{Usia Pasien}

Evaluasi Penggunaan Obat Antituberkulosis Pada Pasien TB Paru Di Rumah Sakit Grandmed Lubuk Pakam diperoleh gambaran distribusi penggunaan obat Antituberkulosis untuk pasien Tb Paru. Berdasarkan Usia Pasien yang dapat Dilihat Pada Tabel 2 dibawah ini.

Tabel 2. Distribusi Usia Pasien TB Pada Periode Januari 2019 S/D Desember 2019.

Untuk karakteristik pasien TB Paru berdasarkan distribusi umur

\begin{tabular}{cccc}
\hline $\begin{array}{c}\mathbf{N} \\
\mathbf{O}\end{array}$ & Karakteristik & $\mathbf{F}$ & $\begin{array}{c}\mathbf{( \% )} \\
(\mathbf{n = 7 6} \\
\mathbf{\%})\end{array}$ \\
\hline 1 & $\begin{array}{l}18-24 \\
\text { Tahun }\end{array}$ & 44 & $57.9 \%$ \\
\hline 2 & $\begin{array}{l}25-40 \\
\text { Tahun }\end{array}$ & 32 & - \\
\hline Total & & 76 & $\begin{array}{c}100.0 \\
\%\end{array}$ \\
\hline
\end{tabular}

digolongkan dalam 2 variasi kelompok, yaitu 18-24 Tahun, Pasien 25- 40 Tahun. Jumlah terbanyak berada pada usia rentang 18-24 tahun yaitu 44 orang $(57.9 \%)$ sedangkan untuk 25 40 Tahun 32 orang (42.1\%).

\section{Karakteristik Pasien Analisis Univariat}

a. Berdasarkan Pekerjaan

Analisis responden untuk karakteristik pasien TB Paru berdasarkan pekerjaan responden digolongkan dalam 5 variasi kelompok, yaitu Wiraswasta berjumlah 3 orang (3.8 \%) , IRT/Ibu rumah tangga berjumlah 15 orang (19.0\%), kemudian Karyawan berjumlah 16 
orang $(20.3 \%)$, Petani 19 orang (24.1 $\%)$, Mahasiswa berjumlah 16 orang (20.3\%). Jumlah pekerjaan responden terbanyak berada pada pasien yang pekerjaan sebagai petani yaitu sebanyak 19 (24.1 \%). Dimana hasil dapat dilihat pada Tabel 4 .

\section{(\%)}

\begin{tabular}{llcc}
$\begin{array}{c}\text { N } \\
\mathbf{O}\end{array}$ & $\begin{array}{c}\text { Pekerjaan } \\
\text { Responden }\end{array}$ & Frekuensi & $\begin{array}{c}(\mathbf{n}=\mathbf{7 6 \%} \\
\text { ) }\end{array}$ \\
\hline 1 & Wiraswasta & 3 & $3.8 \%$ \\
\hline 2 & IRT & 15 & $19.0 \%$ \\
\hline 3 & Karyawan & 16 & $20.3 \%$ \\
\hline 4 & Petani & 19 & $24.1 \%$ \\
\hline 5 & $\begin{array}{l}\text { Mahasisw } \\
\text { a }\end{array}$ & 16 & $20.3 \%$ \\
\hline & Total & 76 & $100.0 \%$
\end{tabular}

\section{Kerasional Penggunaan OAT}

Kerasionalan Penggunaan Obat Antituberkulosis dilakukan terhadap 76 data rekam medik pasien yang menderita TB Paru di Rumah Sakit Grandmed Lubuk Pakam. Evaluasi kerasionalan dilakukan meliputi beberapa kriteria kerasionalan yaitu, Tepat Indikasi, Tepat Pasien, Tepat Obat, Tepat Dosis. Berdasarkan Hasil Penelitian Pada 76 Pasien Diketahui Kerasionalan Obat Antituberkulosis Pada Pasien TB Paru Sebagai Berikut: ( Kemenkes RI, 2011).

\section{a. Tepat Indikasi}

Pengobatan dikatakan tepat indikasi jika pemilihan dan pemberian obat berdasarkan diagnosis yang benar dengan keluhan yang dialami pasien. Indikasi juga jdapat dilihat dari munculnya keluhan pasien yang biasa hadir pada pasien dengan TB paru seperti adanya gejala batuk berdahak, sesak nafas, demam, penurunan berat badan dan keringat malam hari tanpa adanya aktifitas. (Kemenkes RI, 2010).

b. Tepat Pasien

Pengobatan dikatakan tepat pasien jika pemberian pengobatan sesuai dengan patologis serta tidak menimbulkan masalah bila diberikan kepada pasien. Kriteria tepat pasien juga dilihat dari penyakit penyerta lain yang juga diderita oleh pasien dengan riwayat penyakit pasien (Kemenkes RI, 2010).

c. Tepat Obat

Pengobatan tepat obat adalah pemberian pengobatan kepada pasien merupakan obat pilihan pertama (drug of choice) sesuai dengan diagnosis penyakit penyakit, karakteristik pasien, gejala yang dialami pasien. Evaluasi yaitu sebanyak 76 pasien (Kemenkes RI, 2010). Ketepatan Penggunaan obat dapat dilihat pada Tabel 3.

Tabel 4. Ketepatan Obat Rasional

\begin{tabular}{lccc}
\hline $\mathbf{N}$ & $\begin{array}{c}\text { Ketepatan } \\
\text { Obat }\end{array}$ & $\mathbf{F}$ & $\begin{array}{c}\mathbf{( \% )} \\
\mathbf{( n = 7 6 \% )}\end{array}$ \\
\hline 1 & Rasional & 74 & $97.4 \%$ \\
\hline 2 & Irasional & 2 & $2.6 \%$ \\
\hline Total & 76 & $100.0 \%$ \\
\hline
\end{tabular}

Berdasarkan pada tabel 3. maka Ketepatan Obat Rasional pada pasien TB Paru sebanyak 74 pasien (97.4\%). Dan Irasional 2 pasien (2.6\%).

\section{d. Tepat Dosis}

Pengobatan tepat dosis adalah pemberian dosis yang telah sesuai dilihat dari parameter tepat dosis, frekuensi pemberian, rute pemberian serta durasi penggunaan obat. Jika pasien tidak memenuhi keempat 
kriteria tepat dosis tersebut, maka pasien tidak keempat ktiteria tepat dosis tersebut, maka pasien dinyatakan sebagai tidak tepat dosis. Kerasionalan tepat dosis di Rumah Sakit Grandmed Lubuk Pakam (Kemenkes RI, 2010).

\section{KESIMPULAN}

Berdasarkan kerasionalan obat Antituberkulosis pada pasien TB Paru TB Paru dengan meliputi 4 aspek yaitu tepat indikasi, tepat obat, tepat pasien, dan tepat dosis. Dari hasil penelitian yang didapatkan nilai presentase untuk tepat indikasi sebesar $97.4 \%$, tepat obat sebesar $97.4 \%$, tepat pasien $100 \%$, dan tepat dosis sebesar $100 \%$.

\section{DAFTAR PUSTAKA}

Aditama, T, Y. Tuberkulosis Paru (2013). Masalah dan penanggulangan. Penerbit Universitas Indonesia (UIpress) : Jakarta.

Brooks,GFButel J, More AS. (2011). Medical hospital Microbiology. International Edition 22 ed McGraw-Hill. New York.

Hasan H.(2002). Buku Ajar Ilmu Penyakit Paru: Departemen Ilmu Penyakit Paru FK Unair. Surabaya.

Kemenkes RI. (2010). Tuberkulosis Temukan Obat Sampai Sembuh. Pusat Data Dan Informasi Kesehatan RI.Jakarta.

Kementrian Kesehatan Republik Indonesia. (2014). Pedoman Nasional Pengendalian Tuberkulosis. Jakarta.

Misnadiarly, (2011). Penyakit Infeksi TB Paru dan Ekstra Paru,Pada Kehamilan. Edisi penerbit pustaka popular, Bogor.
Megawati, dkk. (2010).Buku Ajar Ilmu Penyakit Paru. PenerbitFK NAIR,Surabaya.

Rubenstein, dkk.(2013) Lecture Notes Kedokteran Klinis. Erlangga Medical Series, Jakarta. 